\title{
Methods for Determining Streambank CRitical Shear Stress and SoIl Erodibility: IMPLICATIONS FOR EROSION RATE PREDICTIONS
}

\author{
L. A. Clark, T. M. Wynn
}

\begin{abstract}
According to the U.S. EPA, excess sediment is a significant cause of water quality impairment for rivers. The goal of this study was to compare different methods of determining two parameters used to estimate streambank erosion, soil critical shear stress $\left(\tau_{c}\right)$ and soil erodibility $\left(k_{d}\right)$ and to determine the impact of those differences on predictions of streambank erosion. At 25 field sites, bank erosion tests were conducted using a submerged jet test device, and soil samples were collected. Critical shear stress was measured using a multi-angle submerged jet test device (JT) and estimated based on Shields' diagram $(S D)$ and empirical relations based on the soil parameters, percent clay $\left(P_{c}\right)$, plasticity index $\left(I_{w}\right)$, particle size $\left(D_{50}\right)$ and percent silt-clay (SC). Additionally, using a single set of $\tau_{c}$ values, the $k_{d}$ measured by the jet test was compared to predictions from two empirical $k_{d}$ relations. Using these parameter values, streambank erosion rates were predicted for a local stream. The jet $\tau_{c}$ estimates were as much as four orders of magnitude greater than the $S D, P_{c}$, and $D_{50}$ estimates, indicating the $S D$ and empirical methods underestimate $\tau_{c}$. The two empirical $k_{d}$ equations produced similar $k_{d}$ values that were generally two orders of magnitude less than the values from the jet test measurements. Erosion predictions followed the same trend as the $k_{d}$ data, with the jet test measurements resulting in higher predictions. Field validation of these methods over a wide range of soil types is recommended to develop methods of estimating $k_{d}$ and $\tau_{c}$ for fine-grained streambank soils.
\end{abstract}

Keywords. Channel erosion, Critical shear stress, Erodibility, Streambank erosion, Stream restoration.

A ccording to Osterkamp et al. (1998), the physical, chemical, and biological damage due to water pollution by sediment costs an estimated $\$ 16$ billion annually in North America. Second only to bacteria, sediment is a common pollutant in streams, causing the impairment of $31 \%$ of assessed stream miles (USEPA, 2002). While considerable effort has been directed toward reducing erosion from agricultural and urban lands, a major source of sediment, stream channel degradation, has largely been ignored. Studies have shown that sediment from streambanks can account for as much as $85 \%$ of watershed sediment yields, and bank retreat rates as high as 1.5 to $1100 \mathrm{~m} /$ year have been documented (Trimble, 1997; Wallbrink et al., 1998; Prosser et al., 2000; Simon et al., 2000). In addition to water quality impairment, streambank retreat impacts floodplain residents, riparian ecosystems, bridges, and other stream-side structures (ASCE, 1998). Improvements in channel retreat predictions are necessary for sediment total maximum daily load (TMDL) determinations and improved

Submitted for review in August 2006 as manuscript number SW 6621; approved for publication by the Soil \& Water Division of ASABE in November 2006. Presented at the 2005 ASAE Annual Meeting as Paper No. 052019 .

The authors are Leslie A. Clark, ASABE Member Engineer, Graduate Assistant, and Theresa M. Wynn, ASABE Member Engineer, Assistant Professor, Department of Biological Systems Engineering, Virginia Tech, Blacksburg, Virginia. Corresponding author: Leslie A. Clark, Biological Systems Engineering, Virginia Tech, 200 Seitz Hall, Blacksburg, VA 24061-0303; phone: 540-231-0695; fax: 540-231-3199; e-mail: lclark3@ vt.edu. watershed management, as required by the U.S. Clean Water Act.

Streambank retreat typically occurs by a combination of three processes: subaerial processes and erosion, fluvial erosion, and bank failure (Lawler, 1995). Subaerial processes are climate-related phenomena that reduce soil strength, inducing direct erosion and making the bank more susceptible to fluvial erosion (e.g., frost heave, desiccation cracking; Thorne, 1982). Fluvial erosion is the direct removal of soil particles or aggregates from the stream bed or bank by stream flow (hereafter called "erosion"), while the collapse of streambanks due to slope instability is referred to as bank failure (Lawler, 1995). Streambank retreat is typically a cyclic process, initiated by the fluvial erosion of the channel bed and/or bank toe, which creates a geotechnically unstable streambank. This instability results in failure of the streambank and deposition of failed material at the bank toe. Subsequent floods remove the failed material and the bank retreat cycle is repeated until the channel widens enough to reduce the boundary shear stress to nonerosive levels (Thorne, 1982).

One key to maintaining or restoring channel stability is to prevent the incision of the channel bed and erosion of the streambanks. While the stream bed elevation is determined by the balance between sediment supply and sediment transport capacity, streambank stability requires that the applied shear stress remain below erosive levels. These erosive levels are quantified by the soil critical shear stress. The critical shear stress $\left(\tau_{c}\right)$ is defined as the stress at which soil detachment begins or the condition that initiates soil detachment. If the critical stress is higher than the effective stress, the erosion rate is considered zero (Osman and 
Thorne, 1988; Nearing et al., 1989; Hanson, 1990a; Hanson et al., 2002). Theoretically, maintenance of the channel boundary shear stress below $\tau_{\mathrm{c}}$ is a requirement for streambank stability. Determination of $\tau_{c}$ is also required to correctly model and understand streambank retreat (Owoputi and Stolte, 1995).

The erosion rate of fine-grained soils due to overland flow or stream channel scour is commonly predicted by the excess shear stress equation (Partheniades, 1965; Hanson and Cook, 1997; Hanson, 1990a, 1990b):

$$
\varepsilon=k_{d}\left(\tau_{a}-\tau_{c}\right)^{a}
$$

where

$\varepsilon=$ erosion rate $(\mathrm{m} / \mathrm{s})$

$k_{d}=$ erodibility coefficient $\left(\mathrm{m}^{3} / \mathrm{N} \cdot \mathrm{s}\right)$

$a$ = exponent typically assumed to be 1

$\tau_{a}=$ applied shear stress on the soil boundary $(\mathrm{Pa})$

$\tau_{c}=$ critical shear stress $(\mathrm{Pa})$.

The excess shear stress equation is used to predict channel erosion in models such as HEC-6, CONCEPTS, SWAT, and HSPF; however, application of the equation has limitations (USACE, 1993; Allen et al., 1997; Bicknell et al., 1997; Langendoen, 2000). While the effective shear stress can be related to flow hydraulics, the soil parameters $\left(\tau_{c}\right.$ and $\left.k_{d}\right)$ are difficult to estimate or measure for fine-grained soils. Many factors, such as soil moisture content, clay content and type, and soil structure, influence the erosion of fine-grained sediment, making $\tau_{c}$ and $k_{d}$ difficult to quantify (Grissinger, 1982). The goal of this study was to compare different methods of estimating the soil parameters $\left(\tau_{c}\right.$ and $\left.k_{d}\right)$ to in situ field measurements and to determine the effects of differences in parameter estimates on streambank erosion estimates.

\section{Estimating Soil Critical Shear STRESS}

There are several approaches for determining $\tau_{c}$. Critical shear stress can be determined in flume studies, estimated based on soil parameters such as particle size and soil specific gravity, measured in situ with a submerged jet test device, or assumed zero. For noncohesive soils, Shields' diagram provides estimates of critical shear stress based on particle size using a representative particle diameter and assuming no interaction among the sediment particles (Shields, 1936; Vanoni, 1977; Hann et al., 1994). This diagram was developed using data from studies of uniform, noncohesive particles for which fluvial entrainment is a function of gravity and hydraulic lift and drag forces. Because there are few methods available to estimate $\tau_{c}$ and Shields' diagram has been extended to include smaller diameter particles, the diagram has been used to estimate $\tau_{c}$ of fine-grained soils (Temple and Hanson, 1994). Considering that the extension of the diagram is not based on actual laboratory or field data, and the effects of interparticle forces outweigh the influence of gravity in the resistance of cohesive soils to erosion, use of Shields' diagram to predict the $\tau_{c}$ of fine-grained soils will likely result in significant underestimation, resulting in overprediction of erosion rates (Hanson and Simon, 2001).

The most widely used erosion measurement technique, particularly for cohesive soils, involves an open-channel flow test with soil forming the bed. The critical stress is then determined visually or graphically. Visually, $\tau_{c}$ is determined by measuring the shear stress at failure. Unfortunately, the point of failure is difficult to define, and most definitions are subjective (Hanson et al., 1999). In a flume study, Kamphuis and Hall (1983) stated that the critical value was reached at "pitting of the surface," while Dunn (1959) determined that the critical value was reached as "the water became cloudy." Smerdon and Beasley (1961) reported the critical value when "general movement of the soil composing the channel bed was observed." To avoid this subjectivity, $\tau_{c}$ can be defined graphically by plotting the erosion rate versus the shear stress with a best-fit straight line. The point where the line crosses the $x$-axis represents the stress at no erosion, or the critical stress (Hanson and Cook, 1997).

Smerdon and Beasley (1961) conducted a flume study on eleven cohesive Missouri soils to relate basic soil properties (plasticity index, dispersion ratio, mean particle size, and percent clay) to the critical shear stress. Soil samples were leveled after placement in the flume but not compacted. As the soil was observed under increasing flow rates, the shear stress corresponding to bed failure was considered $\tau_{c}$. The empirical relations developed between the soil properties and $\tau_{c}$ are shown by equations 2 through 5 :

$$
\begin{gathered}
\tau_{c}=0.16\left(I_{w}\right)^{0.84} \\
\tau_{c}=10.2\left(D_{r}\right)^{-0.63} \\
\tau_{c}=3.54 \times 10^{-28.1 D_{50}} \\
\tau_{c}=0.493 \times 10^{0.0182 P_{c}}
\end{gathered}
$$

where

$\tau_{c}=$ critical shear stress $(\mathrm{Pa})$

$I_{w}=$ plasticity index

$D_{r}=$ dispersion ratio

$D_{50}=$ mean particle size $(\mathrm{m})$

$P_{c}=$ percent clay by weight $(\%)$.

The relations with $I_{w}$ and $D_{r}$ were considered the most reliable in the study because the two parameters are directly related to cohesion properties of the soil.

Neill (1967) presented experimental data on the incipient motion of six sizes of graded gravels, two sizes of uniform glass balls, and cellulose acetate balls ranging in diameter from 6 to $30 \mathrm{~mm}$ for wide channel, uniform flow over a flat bed. Neill presented an equation relating mean velocity to grain size, specific gravity, and flow depth:

$$
\frac{\rho V_{m c}^{2}}{\gamma_{s}^{\prime} D_{g}}=2.50\left(\frac{D_{g}}{d}\right)^{-0.20}
$$

where

$$
\begin{aligned}
V_{m c}= & \text { competent mean velocity for first displacement of } \\
& \text { bed material } \\
D_{g}= & \text { effective diameter of bed grains } \\
d & =\text { depth of flow } \\
\gamma_{s}^{\prime}= & g\left(\rho_{s}-\rho\right) \\
g & =\text { acceleration due to gravity } \\
\rho & =\text { fluid mass density } \\
\rho_{s} & =\text { bed-material mass density. }
\end{aligned}
$$


A form of Neill's equation relating specific gravity, median particle diameter, and water depth to incipient shear stress can be used to estimate $\tau_{c}$ (Neill, 1973; Fairfax County, 2004):

$$
\tau_{c}=0.76090 \gamma\left(S_{g}-1\right) D_{50}^{2 / 3} d^{1 / 3}
$$

where

$\tau_{c}=$ incipient shear stress $(\mathrm{Pa})$

$\gamma=$ specific weight of water $\left(\mathrm{N} / \mathrm{m}^{3}\right)$

$S_{g} \quad=$ specific gravity of soil

$D_{50}=$ median particles diameter $(\mathrm{m})$

$d=$ depth of flow (m).

Because Neill's equation involves depth of flow in the evaluation, $\tau_{c}$ cannot be considered a soil property exclusively. The determination of $\tau_{c}$ depends both on soil properties and on flow conditions, making it difficult to compare the Neill method to other estimation methods.

Julian and Torres (2006) estimated critical shear stress based on the percentage of silt and clay $(S C)$ from results presented by Dunn (1959) and Vanoni (1977). A third-order polynomial was presented in which silt-clay content was defined as particle sizes less than $0.063 \mathrm{~mm}$ :

$$
\begin{aligned}
\tau_{c}= & 0.1+0.1779(S C)+0.0028(S C)^{2} \\
& -2.34 E-5(S C)^{3}
\end{aligned}
$$

The study also accounted for vegetation effects; the $\tau_{c}$ values were multiplied by a vegetation coefficient (ranging from 1 to 19.20) to account for increasing critical shear stresses due to vegetation (Julian and Torres, 2006). This approach differed from previous studies that accounted for vegetation effects in the applied shear stress parameter using shear stress partitioning (Temple, 1980, 1985; Samani and Kouwen, 2002; Thompson et al., 2004).

While flume studies allow a controlled testing environment, it is difficult to place stream bed or bank material in the flume without disturbance (Hanson et al., 1999; Hanson and Cook, 2004). Many factors, such as soil structure, texture, and chemistry, as well as eroding fluid chemistry, influence soil erosion (Grissinger, 1982). Because of these many factors, in situ measurements of $k_{d}$ and $\tau_{c}$ are preferred. Hanson (1990b) designed a submerged jet test device that provides portability and convenience for in situ testing and allows the freedom to test the impact of different soil and environmental conditions on $k_{d}$ and $\tau_{c}$

The submerged jet test device produces a circular jet at a uniform velocity that impinges on the soil bed at right angles (fig. 1). The jet test device consists of a $30.5 \mathrm{~cm}$ diameter steel base ring that is pounded into the soil to a depth of $7.6 \mathrm{~cm}$ to prevent piping of water under the ring. Water is pumped from the stream to a head tank, into the outer jet tube, through the nozzle, and into the tank. The velocity of the jet remains constant and maintains a maximum velocity along the jet centerline. Following impact with the soil surface, the jet diffuses radially, producing a shear stress along the bank. A point gage is used to measure scour depths at regular intervals throughout the test. The jet scours the soil until the maximum scour depth is reached, and the rate of scour equals zero. At this equilibrium, the critical shear stress can be computed. Unfortunately, reaching equilibrium can take anywhere from hours to days (Hanson and Cook, 1997). Due to this limitation, maximum scour depth and the critical shear stress are estimated by fitting a hyperbolic logarithmic equation to the scour data, as described by Blaisdell et al. (1981). The soil erodibility parameter $\left(k_{d}\right)$ is then determined by fitting the jet test scour data to the excess shear stress equation using a least squares method.

Lavelle and Mofjeld (1987) discussed the theoretical merit of a critical shear stress. Because of the turbulent nature of the flow, there are limitations to defining the point of incipient motion; instantaneous fluctuations in the effective shear stress higher than the average shear stress are likely responsible for erosion (Lavelle and Mofjeld, 1987; Chang,

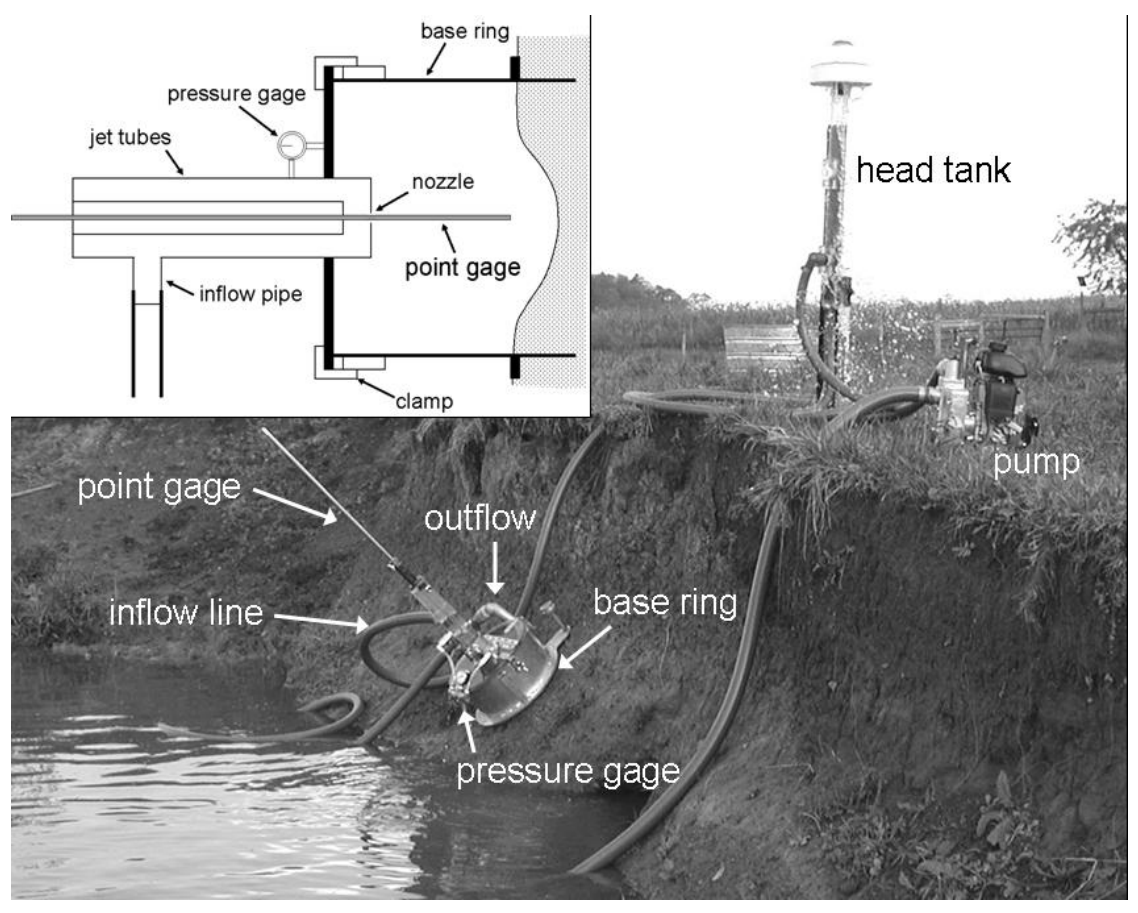

Figure 1. Picture and schematic of the multi-angle submerged jet test device. 
2002). In addition, because the point of incipient motion is difficult to define, $\tau_{c}$ is often considered insignificant and set to zero (Foster et al., 1977; Hanson, 1990b; Temple 1992; Hanson et al., 1999) or given a constant value based on soil properties (Temple, 1980, 1983, 1985).

\section{Estimating SoIl Erodibility}

Although simple relations between $k_{d}$ and soil properties are not available (Hanson and Temple, 2002), two empirical methods exist for estimating $k_{d}$ if $\tau_{c}$ is known. Hanson and Simon (2001) conducted 83 jet tests to determine $\tau_{c}$ and $k_{d}$ for stream beds of highly erodible loess in the midwestern U.S. The beds were typically $50 \%$ to $80 \%$ silt-sized material with a $\tau_{c}$ range of 0.0 to $400 \mathrm{~Pa}$ and a $k_{d}$ range of 0.001 to 3.75 $\mathrm{cm}^{3} / \mathrm{N} \cdot \mathrm{s}$. The study found wide variation in the resistance parameters from the jet test results, but detected an inverse relation between $\tau_{c}$ and $k_{d}$, where $k_{d}$ could be estimated as a function of $\tau_{c}(\mathrm{~Pa})$ :

$$
k_{d}=0.2 \tau_{c}^{-0.5}
$$

where $k_{d}$ is the erodibility coefficient $\left(\mathrm{cm}^{3} / \mathrm{N} \cdot \mathrm{s}\right)$.

Osman and Thorne (1988) presented a form of the excess shear stress equation to estimate the lateral erosion rate for soils with $\tau_{c}$ greater than $0.6 \mathrm{~Pa}$. The method was based on flume experiments conducted at the Waterways Experiment Station in Vicksburg, Mississippi, and used undisturbed cohesive bank soil samples from 42 streams in the U.S. (Arulanandan et al., 1980). Soil erodibility was calculated as the initial lateral bank erosion $(d B)$ divided by $\tau_{c}$. An initial lateral bank erosion rate was defined by a relation linking $\tau_{c}$ to $d B$, as shown in the following equation:

$$
d B=\frac{223 \times 10^{-4} \tau_{c} e^{-0.13 \tau_{c}}}{\gamma}
$$

where

$d B=$ initial lateral bank erosion rate $(\mathrm{m} / \mathrm{min}$ per unit area)

$\tau_{c}=$ critical shear stress $\left(\right.$ dynes $\left./ \mathrm{cm}^{2}\right)$

$\gamma=$ soil unit weight $\left(\mathrm{kN} / \mathrm{m}^{3}\right)$.

The erosion rate was then estimated with a form of the excess shear stress equation:

$$
d W=d B \frac{\left(\tau-\tau_{c}\right)}{\tau_{c}}
$$

where

$d W=$ actual erosion rate $(\mathrm{m} / \mathrm{min})$

$d B=$ initial lateral bank erosion rate $(\mathrm{m} / \mathrm{min}$ per unit area)

$\tau=$ flow shear stress (dynes $/ \mathrm{cm}^{2}$ ).

If the predicted erosion rate was unrealistic, the authors suggested the application of a calibration factor (Osman and Thorne, 1988).

\section{Methodology}

This study compared five methods for estimating $\tau_{c}$, including Shields' diagram and four empirical equations using soil percent clay, plasticity index, mean particle size, and percent silt-clay, to field measurements using a submerged jet test device (Smerdon and Beasley, 1961; Blaisdell et al., 1981; Hann et al., 1994; Julian and Torres, 2006).
Additionally, using a single set of $\tau_{c}$ values, the $k_{d}$ values predicted by the two empirical methods were compared to the predictions of the jet test device (Osman and Thorne, 1988; Hanson and Cook, 1997; Hanson and Simon, 2001). Using these estimated parameters, streambank erosion rates were predicted for a historic storm event on a local stream to evaluate the effect of differences in the estimated parameter values on erosion predictions.

\section{In Situ Measurements with the Jet Test Device}

Twenty-five field sites near the town of Blacksburg in southwest Virginia $\left(37^{\circ} 15^{\prime} \mathrm{N}, 80^{\circ} 25^{\prime} \mathrm{W}\right.$; fig. 2) were tested. The sites are in the Appalachian Mountains with elevations ranging from 350 to $900 \mathrm{~m}$ NGVD29. The climate is typical of temperate mountain regions. The average annual rainfall is about $1100 \mathrm{~mm}$ and has a relatively even distribution throughout the year (Wynn et al., 2004). The sites consisted of a reach of 30 stream-meters along one bank; the streams ranged from 2 nd to 4 th order with drainage areas of 9 to $322 \mathrm{~km}^{2}$. Baseflow water depths varied from 20 to $50 \mathrm{~cm}$ with baseflow channel widths of 3 to $24 \mathrm{~m}$. Bank exposure and bank angles ranged from 65 to $225 \mathrm{~cm}$ and $30^{\circ}$ to $90^{\circ}$, respectively. Bed and bank materials varied from sand to boulders and from clay loam to loamy sand, respectively (Wynn, 2004).

In situ jet tests were conducted on both the upper and lower banks at each site using a multi-angle submerged jet test device (Hanson and Cook, 1997; ASTM, 1999a; Hanson and Cook, 2004). The tests were conducted for $45 \mathrm{~min}$, with scour depth and pressure differential readings taken at 5 min intervals. Using scour and shear stress data from the jet test, $\tau_{c}$ and $k_{d}$ were determined using methods developed by Hanson and Cook (1997). A total of 142 individual jet test runs were conducted from May through August 2003. Three tests were typically run on both the upper and lower banks at each site (six tests per site), except where crayfish burrows or highly erodible soil limited testing.

\section{SoIL Testing}

To estimate $\tau_{c}$ using Shields' diagram (Vanoni, 1977), the Smerdon and Beasley (1961) empirical relations (eqs. 2 through 5), and the Julian and Torres (2006) empirical relation (eq. 8), soil samples of approximately $250 \mathrm{~cm}^{3}$ were taken adjacent to the jet test tank for each jet test run. The soil samples were air-dried prior to analysis for soil particle size distribution, specific gravity, and Atterberg limits. Because the data used in this study were originally developed for an alternate study (Wynn, 2004) that did not consider the dispersion ratio, this soil parameter was not determined. In addition, due to a limitation in the number of soil samples, only 93 tests were used in this study.

To determine the particle size distribution, approximately $50 \mathrm{~g}$ of soil were passed through a No. 10 sieve ( $2 \mathrm{~mm}$ mesh) and analyzed following methods outlined by the USDA (1996). The median particle diameter $\left(D_{50}\right)$ was calculated for each jet test and used as the representative diameter for the soil.

Specific gravity is the ratio of the mass of a unit volume of soil to the mass of an equivalent volume of deionized water. Soil particles with high specific gravity settle quickly and are less likely to be entrained than particles with low specific gravity. The specific gravity of the bank soils was evaluated according to ASTM standard D854-98 (ASTM, 1999b). 


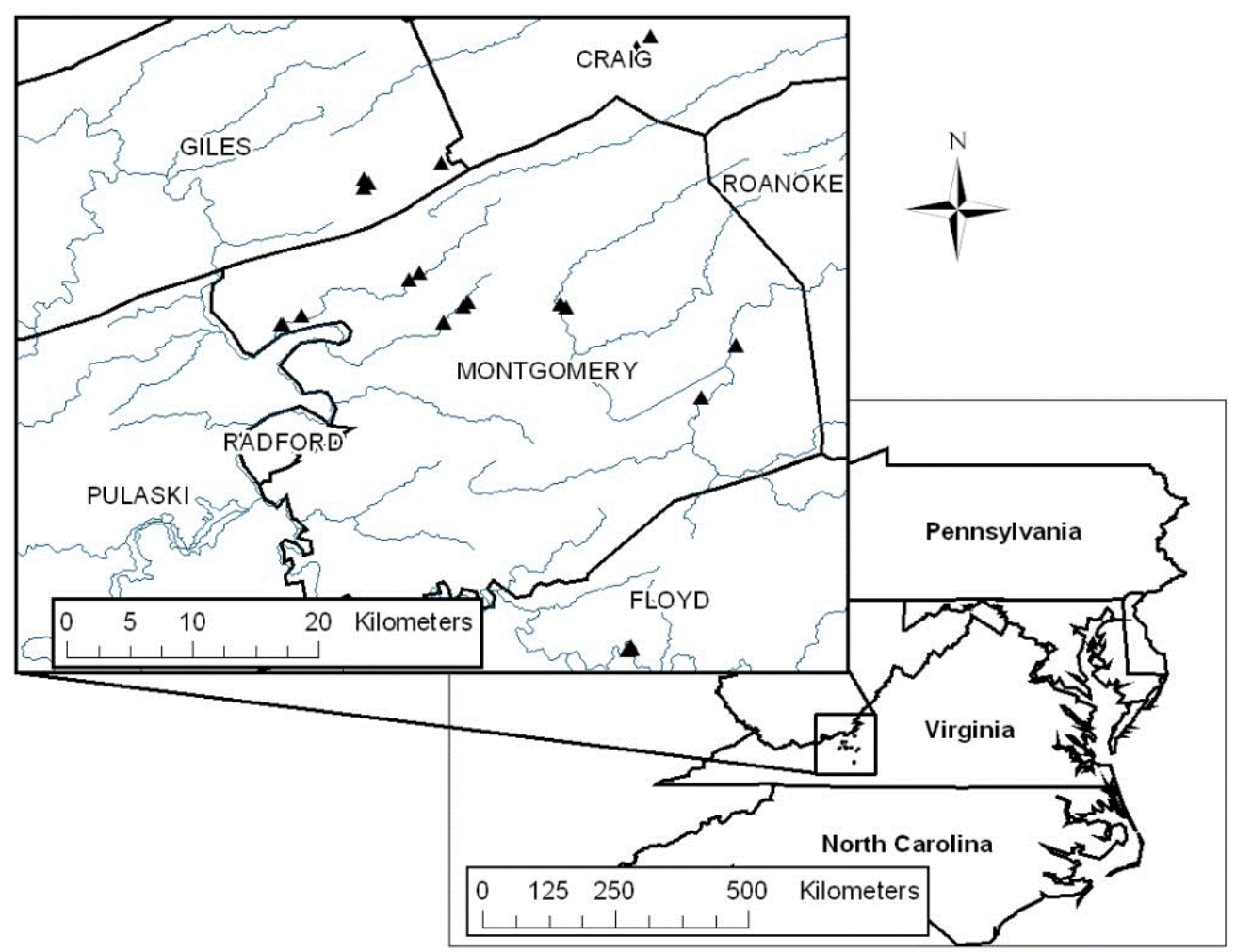

Figure 2. Locations of 25 field sites near the town of Blacksburg in southwest Virginia.

Soil Atterberg limits are the liquid limit, the plastic limit, and the plasticity index. The liquid limit is the lowest moisture content at which viscous flow will occur, while the plastic limit is the lowest moisture content at which a $3.175 \mathrm{~mm}$ diameter soil thread will remain intact during rolling. The difference between these two parameters is the plasticity index, which defines the range of moisture contents over which a soil exhibits plastic behavior. The plasticity index is dependent on the amount and type of clay and is a useful indicator of the character of fine-grained soils (Lambe and Whitman, 1969; Holtz and Kovacs, 1981). Soil Atterberg limits were evaluated for air-dry samples according to ASTM standard D4318-98 (ASTM, 1999c).

Because both soil bulk density and root density influence soil erosion (Wynn and Mostaghimi, 2006a), both parameters were measured for the study soils. Soil bulk density was determined by taking a single undisturbed soil core in a $5 \times$ $5 \mathrm{~cm}$ aluminum cylinder with a slide hammer. The samples were weighed and dried at $105^{\circ} \mathrm{C}$ within $8 \mathrm{~h}$ of collection following procedures outlined in the USDA soil manual (USDA, 1996).

Root samples were taken using a $7 \mathrm{~cm}$ diameter, $15 \mathrm{~cm}$ long, soil corer. To determine root density, the soil cores were soaked in a bucket of water and washed over a No. 35 sieve $(0.5 \mathrm{~mm}$ mesh). The soil and roots retained on the sieve were then placed in a white plastic pan, and the live roots were removed by hand and stored in a refrigerator at $4^{\circ} \mathrm{C}$ until scanning. Root length and root volume were measured using a Régent Instruments STD 1600+ scanner and WinRHIZO analysis software (Régent Instruments, Inc., Quebec, Canada).

\section{Comparison of EMPIRICAL METhods}

Two empirical methods of estimating $k_{d}$ were compared to field measurements from the jet test device. The jet test $\tau_{c}$ data set was used because the Osman and Thorne (1988) approximation is valid only for $\tau_{c}$ greater than $0.6 \mathrm{~Pa}$ and the $\tau_{c}$ values measured with the jet test device were higher than the $\tau_{c}$ values predicted using the empirical relations. Removing values less than $0.6 \mathrm{~Pa}$ from the jet test $\tau_{c}$ data resulted in a data set of $62 \tau_{c}$ values.

The reduced jet test $\tau_{c}$ data set was used to estimate $k_{d}$ by three methods. First, $k_{d}$ was determined by analysis of the jet test field data. Because solving for two unknowns rarely produced a stable solution, Hanson and Cook (1997) determined $\tau_{c}$ first and then evaluated $k_{d}$ using a least squares fit of the scour data to the excess shear stress equation. An Excel spreadsheet developed by Hanson and Cook (1997) was used for the analysis of the jet test data. Soil erodibility was also predicted by the Hanson and Simon (2001; eq. 9) and the Osman and Thorne (1988; eqs. 10 and 11) models.

\section{Erosion Prediction}

Stream geometry and discharge from a local stream gage were used to evaluate the impact of differences in $k_{d}$ on streambank erosion predictions. These example calculations assumed that the streambanks were homogeneous and composed of the soils tested by Wynn and Mostaghimi (2006a). Daily stage heights from an existing U.S. Geological Survey gage station (USGS 2055100) for Tinker's Creek near Daleville, Virginia ( $\left.37^{\circ} 25^{\prime} 03^{\prime \prime} \mathrm{N}, 79^{\circ} 56^{\prime} 08^{\prime \prime} \mathrm{W}\right)$ from 7 to 9 January 1998 were used. The storm event that occurred during this time period reached a maximum stage of $0.98 \mathrm{~m}$ and had a return interval of 1.1 years (Keaton et al., 2005). This 2 nd order stream has a drainage area of $30.3 \mathrm{~km}^{2}$ 


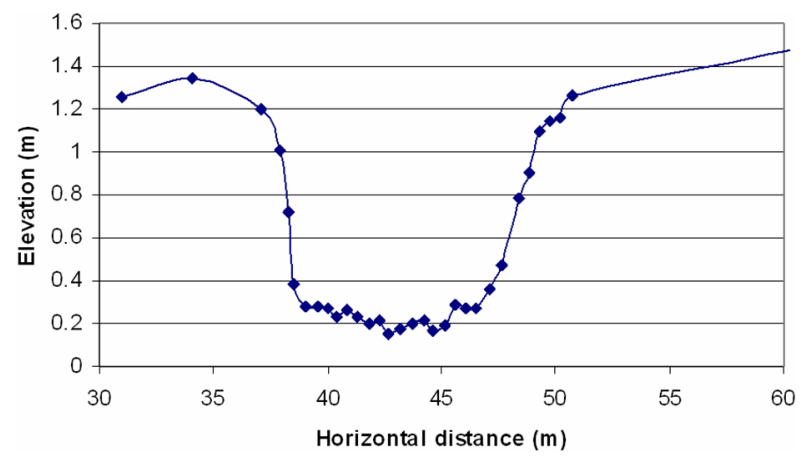

Figure 3. Cross-section of Tinker's Creek used in erosion calculations (Keaton et al., 2005).

$\left(11.7 \mathrm{mi}^{2}\right)$ and a channel gradient of 0.005 at the gage. The bed material at the gage site is gravel with some cobbles and bedrock, and the streambanks are forested with a mixture of understory shrubs and groundcover. The streambanks are generally stable, with isolated areas of bank erosion. The calculations assumed a rectangular, homogeneous, wide crosssection with a $1.1 \mathrm{~m}$ depth (fig. 3; Keaton et al., 2005). While erosion measurements were not made for this storm event, personal observation indicates scour depths are typically no greater than $10 \mathrm{~cm}$ for bankfull storm events on stable streams in this area. This site was selected as an example because headwater streams such as Tinker's Creek are particularly susceptible to degradation by changes in riparian vegetation and/or urban development and are a primary focus of stream restoration efforts in the mid-Atlantic U.S.

Average streambank erosion was estimated by applying the excess shear stress equation (eq. 1) to a unit length of streambank on one side of the stream. The $1.1 \mathrm{~m}$ high bank was split into three sections (fig. 4). If a section was not fully inundated, erosion was only calculated for the area covered with water, and an alternate midpoint was used. For each section, the average applied shear stress was calculated at the section midpoint by equation 12 :

$$
\tau_{a}=\rho g d S
$$

where

$\tau_{a}=$ average applied shear stress at the section midpoint (Pa)

$\rho=$ density of water $\left(\mathrm{kg} / \mathrm{m}^{3}\right)$

$g=$ acceleration due to gravity $\left(\mathrm{m} / \mathrm{s}^{2}\right)$

$d$ = height of water above midpoint $(\mathrm{m})$

$S$ = slope of the energy grade line (approximated by channel slope).

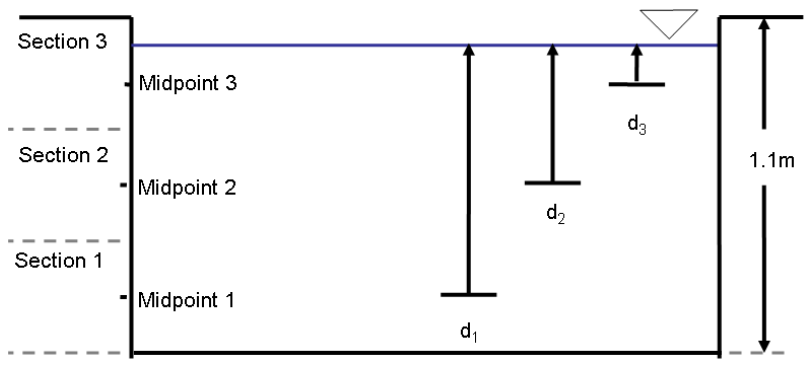

Figure 4. Discretization of streambank for applied shear stress and erosion calculations; midpoint of the top section fluctuated with stage height.
Erosion rates were calculated daily for each section of the streambank by a form of the excess shear stress equation:

$$
\varepsilon=k_{d}\left(\tau_{a}-\tau_{c}\right) h
$$

where

$\varepsilon=$ erosion rate $\left(\mathrm{cm}^{3} / \mathrm{s}\right.$ per unit length of streambank)

$\tau_{c}=$ soil critical shear stress $(\mathrm{Pa})$

$k_{d}=$ erodibility coefficient $\left(\mathrm{cm}^{3} / \mathrm{N} \cdot \mathrm{s}\right)$

$h=$ height of inundated section (m).

The erosion rate was multiplied by $1 \mathrm{~m}$ to determine erosion over a unit length of streambank. Total erosion volumes were calculated for each day and summed to get a total erosion volume for the storm event. The erosion volumes were then divided by $1.1 \mathrm{~m}^{2}$ to determine an average total erosion depth in meters for the three-day period. The estimated storm erosion depth was calculated using the $\tau_{c}$ measured with the jet test device and the $k_{d}$ values measured in the field and estimated using the Hanson and Simon (2001) and the Osman and Thorne (1988) models, resulting in three erosion predictions for each soil tested.

\section{Statistical Analysis}

Because the data did not follow a Gaussian distribution, a Mann-Whitney U test was used to evaluate differences among $\tau_{c}, k_{d}$, and the erosion estimates (Neave and Worthington, 1988). The Wilcoxon signed rank test was used to determine if the calculated $\tau_{c}$ values were significantly different from zero and to determine if pairwise differences between the methods were significantly greater than zero (Daniel, 1990). A significance level of $\alpha=0.05$ was assumed.

\section{RESUlts AND DisCuSSION}

The streambank soils ranged from a clay loam to a sandy loam, with $D_{50}$ values of 0.01 to $0.26 \mathrm{~mm}$ and specific gravities of 2.19 to 2.70 . The soils generally had low plasticity; 33 samples were nonplastic, while the remaining 60 samples had plasticity indexes of 4 to 26 . As discussed in Grissinger et al. (1981), these fine-grained soils with low plasticity exhibit properties between cohesive and noncohesive soils that are not dependent exclusively on particle mass or interparticle electrochemical interactions. Based on Hanson's (1991) definition of cohesive soils (plasticity index $>10$ ), 42 samples were considered cohesive and 51 samples were considered noncohesive. Bulk densities varied from $0.38 \mathrm{~g} / \mathrm{cm}^{3}$ for a recently deposited saturated sandy loam to $1.59 \mathrm{~g} / \mathrm{cm}^{3}$ for a silt loam, with a median value of $1.22 \mathrm{~g} / \mathrm{cm}^{3}$. Root length densities and root volume ratios ranged from 0.1 to $22.6 \mathrm{~cm} / \mathrm{cm}^{3}$ and from 0.0004 to $0.1300 \mathrm{~cm}^{3} / \mathrm{cm}^{3}$, respectively.

\section{Comparison of Critical Shear Stress Estimation METHODS}

Critical shear stresses measured in situ with the jet test device and estimated using Shields' diagram (SD), soil percent clay $\left(P_{c}\right)$, median particle size $\left(D_{50}\right)$, plasticity index $\left(I_{w}\right.$; eqs. 2,4 , and 5$)$, and percent silt-clay ( $S C$; eq. 8$)$ had median values of $2.2,0.1,0.84,0.05,1.25$, and $11.81 \mathrm{~Pa}$, respectively (table 1 ). Because not all of the soils exhibited plastic behavior, the sample size $(n)$ for equation 2 was 60 , as compared to $n=93$ for the other analyses. The median $\tau_{c}$ estimates for all methods were statistically greater than the zero $(\alpha=0.05)$. 
Table 1. Median and range for the jet test, Shields' diagram (SD), percent clay $\left(P_{c}\right)$, median particle size $\left(D_{50}\right)$, percent silt-clay $(S C)$, and plasticity index $\left(I_{w}\right)$ estimates of the streambank critical shear stress $\left.\boldsymbol{\tau}_{\mathfrak{c}}\right)$.

\begin{tabular}{ccccc}
\hline & & \multicolumn{3}{c}{$\tau_{c}(\mathrm{~Pa})$} \\
\cline { 3 - 5 } Method & $n$ & Median & Minimum & Maximum \\
\hline Jet test & 93 & 2.22 & 0 & 21.91 \\
SD & 93 & 0.1 & 0.02 & 0.19 \\
$P_{c}$ & 93 & 0.84 & 0.58 & 1.74 \\
$D_{50}$ & 93 & 0.05 & 0 & 1.69 \\
$S C$ & 93 & 11.81 & 3.57 & 21.53 \\
$I_{w}$ & 60 & 1.25 & 0.55 & 2.51 \\
\hline
\end{tabular}

Comparing estimates for individual sites, the $\tau_{\mathrm{c}}$ measured with the jet test device was as much as four orders of magnitude greater than the $\mathrm{SD}, P_{c}$, and $D_{50}$ estimates at some study sites (fig. 5). While statistically greater than zero $(\mathrm{p}<$ $0.0001), \tau_{c}$ values from the Shields' diagram were all less than $0.2 \mathrm{~Pa}$; from a practical standpoint, Shields' $\tau_{c}$ estimates for these fine-grained soils were essentially equivalent to a value of zero. Developed for noncohesive bed sediments, Shields' diagram assumes no interaction between the soil particles; thus, Shields' diagram is based on median particle size and specific gravity. The soils in this study were fine grained, and $55 \%$ of the soils were cohesive, indicating that interparticle forces, rather than gravity, influenced their erosion.

To evaluate if other streambank characteristics, such as the soil bulk density, root density (RLD and RVR), or plasticity index influenced the differences between the jet test measurements and the predicted values, correlation between the percent difference (\% diff) between the predicted $\tau_{c}$ and the jet test $\tau_{c}$ and the bank properties was investigated by calculating the Pearson correlation coefficient in Minitab for all $\tau_{c}$ estimation techniques (Minitab, Inc., State College, Pa.). Because the percent difference values were highly skewed and contained some negative values, the data were transformed using $\log _{10}(n+\%$ diff $)$ prior to analysis, for which $n$ ranged from 2 to 1000 . The analysis did not reveal correlation between the bank characteristics and percent differences, suggesting that the error associated with the empirical methods was not associated with soil bulk density, root density, or plasticity index.

Hanson and Simon (2001) tested cohesive stream beds in the loess areas of the midwestern U.S. and determined that the measured critical shear stresses of the clay stream beds were equivalent to noncohesive clasts with diameters on the order of 1 to $100 \mathrm{~mm}$. This study confirmed that using Shields' diagram to estimate the $\tau_{c}$ of fine-grained soils may result in significant underestimation.

When comparing the pairwise differences between the jet test measurements and the methods presented by Smerdon and Beasley (1961), the Smerdon and Beasley equations generally underestimated $\tau_{c}(p<0.001)$, likely because these three methods were based on laboratory tests of relatively uniform remolded soils. Sediment structure was likely reduced during sampling, and placement in the flume due to leveling, hydrating, and drying, reducing the shear stress at which sediment detachment occurred. In addition, these three methods depended only on a single soil parameter (percent clay, median particle size, or plasticity index). The soils tested in this study had small ranges of $D_{50}$, specific gravity, and percent clay, which limited the possible $\tau_{c}$ estimates. In contrast, in situ scour tests using the jet test device had greater variability, as they were conducted in the field and likely reflected natural variability in soil structure and physical and chemical properties. The jet test device measured the cumulative effects of soil texture, clay type, specific gravity, moisture content and cohesion, as well as other factors shown to influence soil erosion, such as root reinforcement and soil/eroding fluid chemical interactions (Grissinger, 1982; Kamyab, 1991; Wynn and Mostaghimi, 2006a).

Critical shear-stress estimates based on the $S C$ method (Julian and Torres, 2006) were statistically higher than those of all other methods ( $p<0.001$; fig. 5), resulting in $\tau_{c}$ values as much as four orders of magnitude greater than the

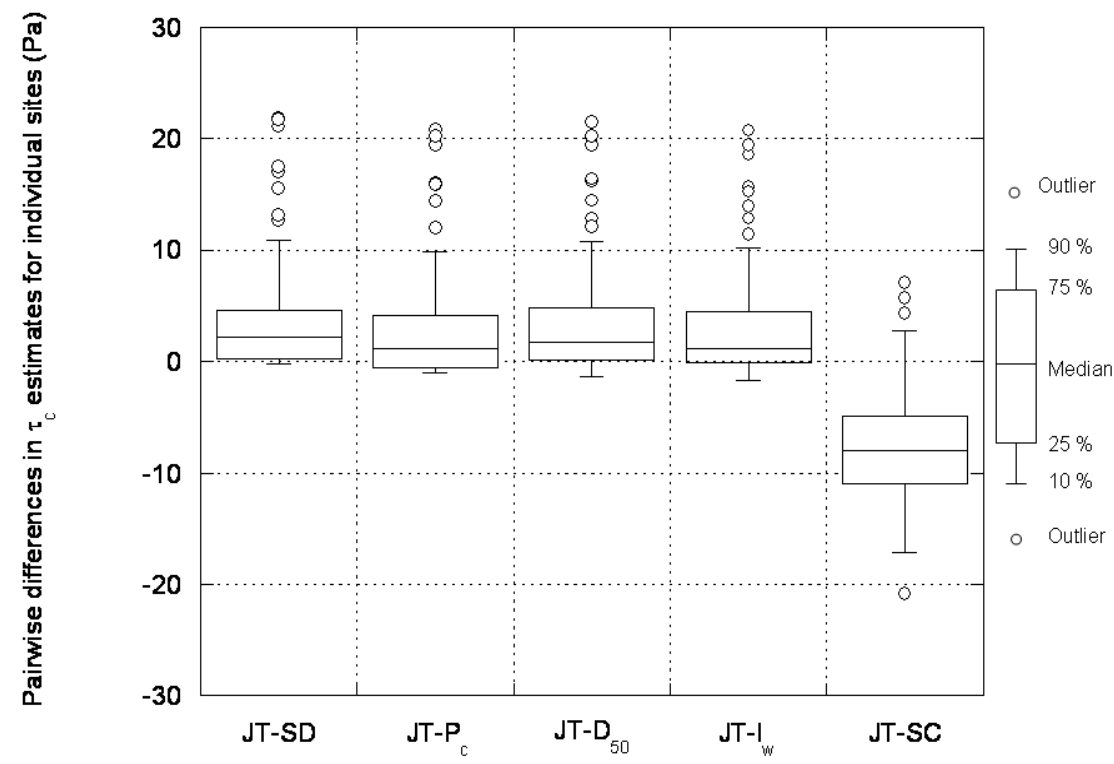

Figure 5. Pairwise differences in critical shear stress $\left(\tau_{c}\right)$ values measured using the submerged jet test device (JT) and estimated using Shields' diagram $(\mathrm{SD})$, and empirical equations based on percent clay $\left(P_{c}\right)$, mean particle size $\left(D_{50}\right)$, plasticity index $\left(I_{w}\right)$, and percent silt-clay $(S C)$; $n=93$ for $\mathrm{SD}, P_{c}$, $S C$, and $D_{50} ; n=60$ for $I_{w}$. 
empirical methods. While $S C$ content for this study (16\% to $88 \%$ ) fell within the range of the soils used in the regression development ( $5 \%$ to $95 \%$ ), the $\tau_{c}$ values measured by the jet test were statistically smaller than the $S C$ estimates. The high estimates can be attributed to the data used to develop the $S C$ relation (Dunn, 1959). Although Dunn (1959) also measured $\tau_{c}$ using a submerged jet test, the samples were reconstructed before measurement by sieving, drying, and consolidating. These methods likely increased soil strength, resulting in high $\tau_{c}$ estimates. After incorporating a vegetation coefficient (ranging from 1 to 19.2), the $S C$ method resulted in $\tau_{c}$ values as much as five orders of magnitude greater than the empirical methods. It should be noted that the Julian and Torres model incorporates both the physical reinforcement provided by the roots and the reduction in hydraulic shear stress into a single multiplier of $\tau_{c}$. A more physically based model would represent the impact of vegetation on stream hydraulics by reducing the applied shear stress $\left(\tau_{a}\right)$.

\section{Comparison of SoIl Erodibility Estimates}

To compare two empirical methods of estimating $k_{d}$ with the in situ jet test measurements, jet test $\tau_{c}$ values were used to estimate $k_{d}$ based on the procedures outlined by Hanson and Simon (2001) and Osman and Thorne (1988). Because the Osman and Thorne method is only valid for $\tau_{c}$ greater than $0.6 \mathrm{~Pa}$, some of the lower jet test $\tau_{c}$ values were omitted, resulting in 62 samples with a median $\tau_{c}$ of $3.66 \mathrm{~Pa}$ and a range of 0.72 to $21.9 \mathrm{~Pa}$.

The $k_{d}$ estimates for the Hanson and Simon (2001) and Osman and Thorne (1988) empirical methods were similar, with median values of 0.10 and $0.13 \mathrm{~cm}^{3} / \mathrm{N} \cdot \mathrm{s}$ and ranges of 0.04 to $1.07 \mathrm{~cm}^{3} / \mathrm{N} \cdot \mathrm{s}$ and 0 to $6.08 \mathrm{~cm}^{3} / \mathrm{N} \cdot \mathrm{s}$, respectively. Evaluating the pairwise differences for individual soils (fig. 6), the measurements using the jet test device were significantly higher than $k_{d}$ estimates by the empirical methods $(\mathrm{p}<0.001)$, and the Osman and Thorne $k_{d}$ estimates were significantly larger than the Hanson and Simon values $(\mathrm{p}=0.002)$. There were several outliers: the jet test measurements of $k_{d}$ were as much as two orders of magnitude higher than the other two methods. The maximum difference between the two empirical methods was one order of magnitude.

To evaluate if streambank soil bulk density, root density (root length density and root volume ratio,), or plasticity index $\left(I_{w}\right)$ influenced the differences between the jet test measurements and empirical methods, correlation among the percent difference (\% diff) between the empirical $k_{d}$ values and the jet test $k_{d}$ and the bank properties was investigated by calculating the Pearson correlation coefficient in Minitab (Minitab, Inc., State College, Pa.). Because the percent difference values were highly skewed and contained negative values, the data were transformed using $\log _{10}(2+\%$ diff $)$ prior to analysis. The correlation analysis did not reveal correlation between the bank characteristics and percent differences $(\alpha=0.05)$, suggesting that the error associated with the two empirical methods was not related to bulk density, root density, or plasticity index.

The range of the $k_{d}$ values for the Hanson and Simon (2001) method was smaller than that for the other two methods because the empirical equation was only dependent on $\tau_{c}$. The Osman and Thorne (1988) method depended on both $\tau_{c}$ and soil unit weight. Hanson and Simon (2001) conducted 83 jet test measurements to determine an empirical relation for $k_{d}$ based on $\tau_{c}$ (eq. 9). Their study reported $\tau_{c}$ values ranging from 0.0 to $400 \mathrm{~Pa}$ and $k_{d}$ values ranging from 0.001 to $3.75 \mathrm{~cm}^{3} / \mathrm{N} \cdot \mathrm{s}$. Because their empirical equation was based on jet test results and the $\tau_{c}$ values used in this study fell within the range used to develop the equation, the $k_{d}$ values estimated by the Hanson and Simon (2001) empirical equation and the jet test $k_{d}$ measurements theoretically should have been similar. In actuality, the jet test measurements from this study were significantly higher than those predicted by the Hanson and Simon equation ( $\mathrm{p}<0.001)$. Because in situ testing incorporates multiple factors that influence erosion, such as soil texture, specific gravity, moisture content, cohesion, root reinforcement, and soil/ eroding fluid chemical interactions, empirical relations developed for one region may not be applicable in other

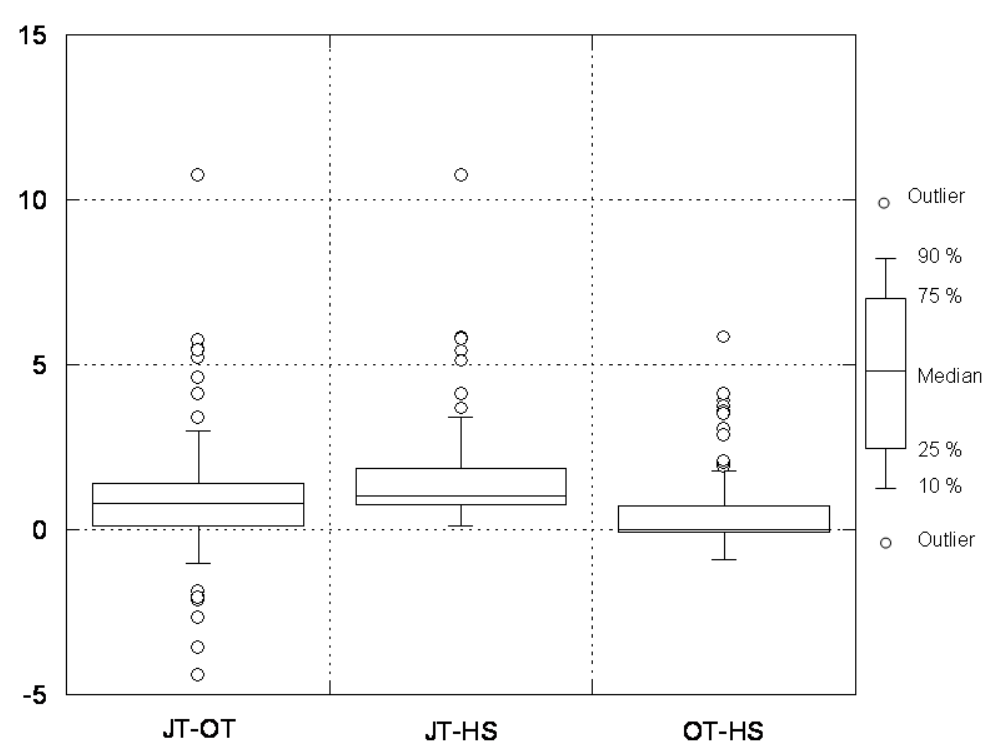

Figure 6. Pairwise differences in soil erodibility $\left(k_{d}\right)$ values determined from submerged jet test measurements and two empirical methods $(n=62$; OT $=$ Osman and Thorne, 1988; HS = Hanson and Simon, 2001). 
areas. Additionally, Hanson and Simon tested stream beds, while this study focused on streambanks. It is possible that stream beds may be more resistant to erosion because they are frequently submerged and therefore not exposed to subaerial processes. Differences between the measured $k_{d}$ and those estimated by the Hanson and Simon (2001) equation also may reflect differences in the jet testing procedure. The test duration for Hanson and Simon's study was 120 min with a 10 min sampling interval, compared to a 45 min test duration for this study, with scour readings taken every $5 \mathrm{~min}$. Because the soils on the streambank surface are exposed to weathering, they tend to be more erodible (Wynn and Mostaghimi, 2006b; Henderson et al, 2006); thus, shorter test times may result in higher $k_{d}$ estimates because the more resistant soils deeper in the streambank are not reached during the shorter test duration. Field validation of these methods over a wide range of soil types is recommended to further develop methods of estimating $k_{d}$ for streambank soils.

\section{Comparison of Streambank Erosion Estimates}

The effect of differences in the $k_{d}$ values on streambank erosion predictions was also evaluated. Using the $\tau_{a}$ values calculated for the example storm, the average streambank erosion depths were predicted for each of the $k_{d}$ estimates. To estimate streambank erosion, the applied shear stress $\left(\tau_{a}\right)$ was calculated using equation 12 . For the inundated streambank sections, $\tau_{a}$ ranged from 2.9 to $36.1 \mathrm{~Pa}$. Because the erosion predictions were directly related to the soil erodibility (eq. 1), the predicted erosion rates showed a similar trend as the $k_{d}$ values. With a median value of $2.02 \mathrm{~m}$ and a range of 0.09 to $20.4 \mathrm{~m}$, the overall erosion estimated by the measured jet test erosion parameters was significantly greater than the erosion predicted by the empirical parameters $(\mathrm{p}<0.001)$. The median streambank erosion depths predicted by the Hanson and Simon (2001) and Osman and Thorne (1988) equations were statistically similar $(p=0.56)$, with values of 0.20 and $0.24 \mathrm{~m}$, respectively. While the median erosion estimates were similar, the Osman and Thorne equation predicted high $k_{d}$ and erosion rates for soils with low $\tau_{c}$ values. The small range of the Hanson and Simon $k_{d}$ values influenced the erosion calculations, keeping the range of erosion estimates lower than that predicted by the Osman and Thorne method or the jet test measurements. These lower streambank erosion estimates reflected the lower $k_{d}$ values predicted by the two empirical methods.

For individual soils, erosion predictions based on the jet test measurements were significantly higher $(\mathrm{p}<0.001)$ than estimates based on the Osman and Thorne (1988) or Hanson and Simon (2001) equations; median differences were 1.07 and $1.81 \mathrm{~m}$, respectively. Both the jet test measurements and the Osman and Thorne equation resulted in some erosion predictions that were as much as two orders of magnitude higher than the erosion estimated using the Hanson and Simon relation (fig. 7).

While the erosion predictions based on the Hanson and Simon parameters were more realistic than predictions based on the jet test measurements or the Osman and Thorne equation, these calculations do not take into account the influence of bed and bank roughness on the applied shear stresses. More realistic erosion rates would likely have been obtained if the applied shear stresses had been estimated using shear stress partitioning to account for the coarse bed material and woody bank vegetation at the gage site. Osman and Thorne (1988) recognized that vegetation impacts streambank stability and noted a limitation in their erosion prediction process because it did not consider the influence of vegetation. Thompson et al. (2004) evaluated spatial and temporal variations in particle shear for idealized, non-submerged rigid vegetal elements. Particle shear and vegetal shear were determined for vegetated densities ranging from 0.03 to $0.09 \mathrm{~m}^{2} / \mathrm{m}^{2}$. Their study showed that particle shear was reduced to a range of $13 \%$ to $89 \%$ of total shear due to vegetation cover. After reducing $\tau_{a}$ to $50 \%$ of the original value, erosion depths were recalculated. The reduction in $\tau_{a}$ decreased median erosion depths to $0.7 \mathrm{~m}, 0.09 \mathrm{~m}$, and $0.075 \mathrm{~m}$ for the jet test, Osman and Thorne, and Hanson and

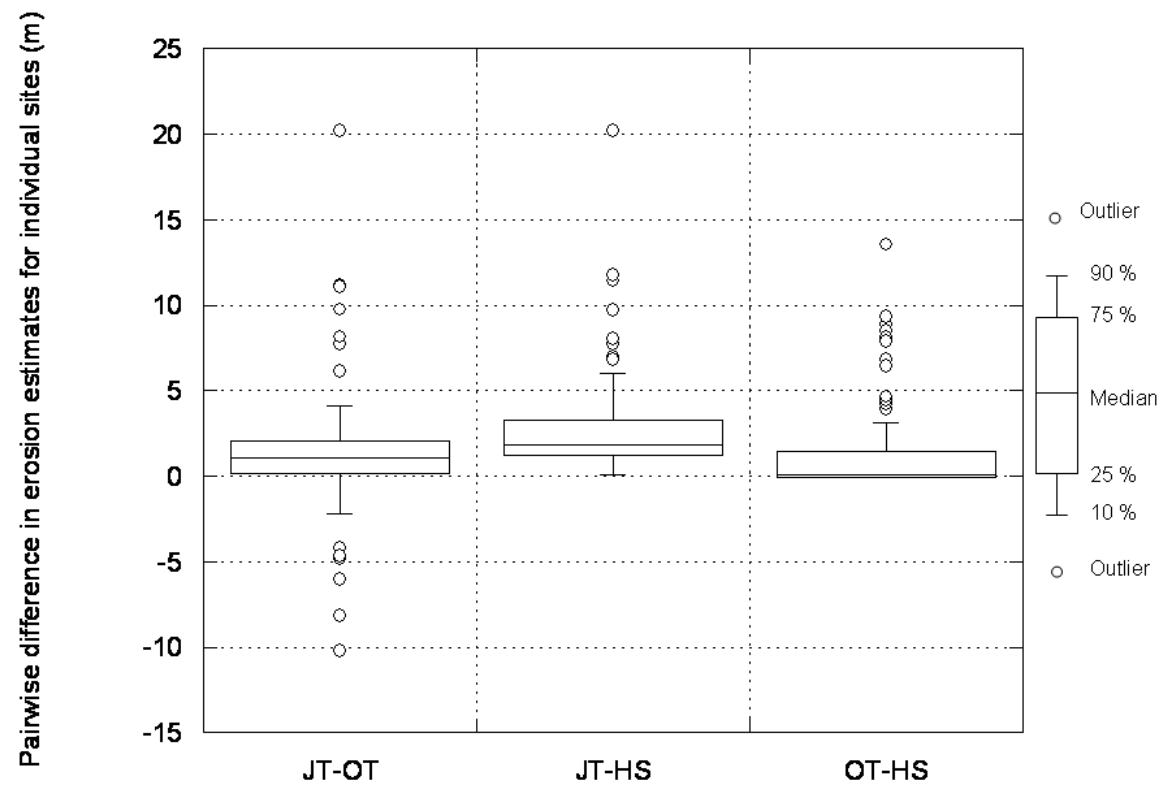

Figure 7. Pairwise differences in streambank erosion predictions based on parameters obtained using two empirical methods (OT $=$ Osman and Thorne, 1988; HS = Hanson and Simon, 2001) and field measurements using the submerged jet test device $(n=62$; Hanson and Cook, 1997). 
Simon $k_{d}$ values, respectively. This difference accounted for a reduction of $62 \%$ to $65 \%$ in median values; maximum erosion values were decreased by $52 \%$ to $62 \%$. Because vegetation is likely to reduce streambank erosion, Julian and Torres (2006) incorporated a vegetation coefficient as a multiplication factor for $\tau_{c}$ to account for vegetation effects. The vegetation coefficients were 5.40 and 19.20 for sparse and dense trees, respectively. If a coefficient was included in this study, the $\tau_{c}$ values would be closer to the $\tau_{a}$ values, resulting in more reasonable erosion predictions. One drawback to this multiplication factor is that it lumps soil reinforcement and particle shear stress reduction from bank vegetation into one parameter, which does not allow a process-based evaluation of the influence of vegetation on bank retreat.

Of the two methods used to account for the influence of riparian vegetation on streambank erosion (reducing $\tau_{a}$ or increasing $\tau_{c}$ ), the former has more theoretical merit. Research by Mamo and Bubenzer (2001a, 2001b) and Wynn and Mostaghimi (2006a) indicated no correlation between $\tau_{c}$ and root density. Riparian vegetation influences the applied soil shear stress by reducing near-bank velocities and dampening near-bank turbulent fluctuations (ASCE, 1998). When examining drag from two types of vegetation (simulated flexible rods and rods with foliage) in a flume study, Wilson et al. (2003) determined that the drag exerted by plants reduced the mean velocity within vegetated regions and decreased shear-generated turbulence by reducing momentum exchange.

This analysis showed that if erosion predictions are the ultimate goal for erosive streambanks under high applied shear stresses, then the selected $k_{d}$ estimation method significantly influences erosion predictions. Because the soils evaluated in this study were fine grained and erosive, the erosion predictions were most influenced by estimations of $\tau_{a}$ and $k_{d}$; therefore, these parameters must be correctly estimated to predict streambank erosion accurately.

\section{Summary AND CONCLUSIONS}

The goal of this study was to compare different methods of estimating the parameters used in the excess shear stress equation for the erosion of fine-grained streambank soils. The specific objectives were to compare empirical estimates of $\tau_{c}$ and $k_{d}$ to field measurements and to determine the effects of differences in the $k_{d}$ value on streambank erosion predictions. This study examined the Shields' diagram, as well as the Julian and Torres (2006) and Smerdon and Beasley (1961) equations, for estimating $\tau_{c}$. Using a single set of $\tau_{c}$ values, the $k_{d}$ values predicted by two empirical relations were also compared to field measurements using the jet test device (Osman and Thorne, 1988; Hanson and Cook, 1997; Hanson and Simon, 2001). These parameter values were then used to estimate streambank erosion for a single storm event on a local stream. These analyses assumed that the jet test measurements were accurate. Additional research is needed to verify the accuracy and precision of the multi-angle submerged jet test device.

With the exception of the $S C$ estimates, measured $\tau_{c}$ values were much higher than those predicted by the empirical equations, suggesting that $\tau_{c}$ is site-specific and should be measured in situ. For the individual fine-grained soils, the jet test measurements resulted in $\tau_{c}$ values as much as four orders of magnitude greater than the Shields' diagram, $P_{c}$, and $D_{50}$ estimates. The Shields' diagram $\tau_{c}$ estimates resulted in $\tau_{c}$ values less than $0.2 \mathrm{~Pa}$, confirming previous findings that using Shields' diagram to estimate the $\tau_{c}$ of fine-grained soils will likely result in underestimation of $\tau_{c}$ (Hanson and Simon, 2001). The jet test measurements incorporated the effects of several factors shown to influence soil erosion, such as soil texture, specific gravity, moisture content and cohesion, root reinforcement, and soil/eroding fluid chemical interactions. Shields' diagram, Smerdon and Beasley (1961), and Julian and Torres (2006) estimates are only dependent on one or two soil parameters. With the exception of the $S C$ analysis, the jet test measurements had a greater range than the other $\tau_{c}$ estimation methods. The narrow range of estimated $\tau_{\mathrm{c}}$ values was likely due to the small range in measured soil parameters. Considering previous research findings (Arulanandan et al., 1980; Wynn and Mostaghimi, 2006a), the results suggest that critical shear stress is influenced by multiple soil properties and may not be modeled by a single dependent parameter. Other variables, such as clay mineralogy, chemistry of the eroding fluid, and antecedent water content, influence $\tau_{c}$, but these variables are seldom measured (Wynn and Mostaghimi, 2006a).

Measured $k_{d}$ values were much higher than those predicted by the empirical equations, suggesting that $k_{d}$ is also site-specific and should be measured in situ. The median $k_{d}$ produced by the jet test measurements was significantly greater than that produced by the two empirical methods, while the $k_{d}$ estimates for the Hanson and Simon (2001) and Osman and Thorne (1988) empirical methods were statistically similar. For individual soils, the jet test resulted in estimates as much as two orders of magnitude greater than the empirical methods. Because the Hanson and Simon (2001) method was based on submerged jet test data and the $\tau_{c}$ data fell within the range, similar results were expected. The differences in $k_{d}$ estimates were attributed to differences in jet testing procedure, location of measurements within the cross-section, and geographic location.

Erosion predictions were directly related to $k_{d}$ data, indicating that erosion rates for streams with low $\tau_{c}$ values are largely controlled by $k_{d}$. The parameters measured by the jet test resulted in significantly and unrealistically high erosion predictions. These results also showed that $\tau_{a}$ has a large impact on streambank erosion calculations. Reducing the $\tau_{a}$ values by $50 \%$ reduced the median erosion estimates up to $65 \%$, indicating that shear stress partitioning that accounts for riparian vegetation and bedforms may be necessary to accurately predict streambank erosion rates. Field validation of these methods over a wide range of soil types is recommended to further develop methods of estimating $k_{d}$ and $\tau_{c}$ for fine-grained streambank soils.

\section{ACKNOWLEDGEMENTS}

The authors would like to thank Jeff Keaton and Alan Simpson, formerly with the Water Resources Division of the U.S. Geological Survey, for providing the survey data for the Tinker Creek gage. The authors also thank Dr. Greg Hanson of the USDA-ARS Hydraulics Laboratory in Stillwater, Oklahoma, for use of the jet test device. 


\section{REFERENCES}

Allen, P. M., J. Arnold, and E. Jakubowski. 1997. Design and testing of a simple submerged-jet device for field determination of soil erodibility. Environ. Eng. Geosci. 3(4): 579-584.

Arulanandan, K., E. Gillogley, and R. Tully. 1980. Development of a quantitative method to predict critical shear stress and rate of erosion of natural undisturbed cohesive soils. Tech. Report GL-80-5. Vicksburg, Miss.: U.S. Army Corps of Engineers.

ASCE. 1998. River width adjustment: I. Processes and mechanisms. J. Hydraulic Eng. 124(9): 881-902.

ASTM. 1999a. Standard test method for erodibility determination of soil in the field or in the laboratory by the jet index method. No. D5852-95, 04.08: 686-690. West Conshohocken, Pa.: ASTM.

ASTM. 1999b. Standard test methods for specific gravity of soil solids by water pycnometer. No. D854-92, 4.08: 89-92. West Conshohocken, Pa.: ASTM.

ASTM. 1999c. Standard test methods for liquid limit, plastic limit, and plasticity index of soils. No. D4318-98, 4.08: 526-538. West Conshohocken, Pa.: ASTM.

Bicknell, B. R., J. C. Imhoff, J. L. Kittle, Jr., A. S. Donigian, Jr., and R. C. Johanson. 1997. Hydrological Simulation Program Fortran, User's Manual for Version 11. EPA/600/R-97/080. Washington, D.C.: EPA.

Blaisdell, F. W., L. A. Clayton, and G. G. Hebaus. 1981. Ultimate dimension of local scour. J. Hydraulic Div. ASCE 107(HY3): 327-337.

Chang, H. H. 2002. Fluvial Processes in River Engineering. Malabar, Fla.: Krieger Publishing.

Daniel, W. W. 1990. Applied Nonparametric Statistics. Boston, Mass.: PWS-Kent.

Dunn, I. S. 1959. Tractive resistance of cohesive channels. J. Soil Mech. and Foundations Div. 85(SM3): 1-24.

Fairfax County. 2004. Outfall analysis based on incipient shear stress method. Fairfax, Va.: Fairfax County (Virginia) Department of Public Works and Environmental Services, Environmental and Site Review Division.

Foster, G. R., L. D. Meyer, and C. A. Onstad. 1977. An erosion equation derived from basic erosion principles. Trans. ASAE 20(4): 678-682.

Grissinger, E. H. 1982. Bank erosion of cohesive materials. In Gravel-Bed Rivers, 273-287. R. D. Hey, J. C. Bathurst, and C. R. Thorne, eds. New York, N.Y.: John Wiley and Sons.

Grissinger, E. H., W. C. Little, and J. B. Murphey. 1981. Erodibility of streambank materials of low cohesion. Trans. ASAE 24(3): 624-630.

Hann, C. T., B. J. Barfield, and J. C. Hayes. 1994. Design Hydrology and Sedimentology for Small Catchments. San Diego, Cal.: Academic Press.

Hanson, G. J. 1990a. Surface erodibility of earthen channels at high stresses: Part I. Open channel testing. Trans. ASAE 33(1): 127-131.

Hanson, G. J. 1990b. Surface erodibility of earthen channels at high stresses: Part II. Developing an in situ testing device. Trans. ASAE 33(1): 132-137.

Hanson, G. J. 1991. Development of a jet index to characterize erosion resistance of soils in earthen spillways. Trans. ASAE 34(5): 2015-2020.

Hanson, G. J., and K. R. Cook. 1997. Development of excess shear stress parameters for circular jet testing. ASAE Paper No. 972227. St. Joseph, Mich.: ASAE.

Hanson, G. J., and K. R. Cook. 2004. Apparatus, test procedures, and analytical methods to measure soil erodibility in situ. Applied Eng. in Agric. 20(4): 455-462.

Hanson, G. J., and A. Simon. 2001. Erodibility of cohesive streambeds in the loess area of the midwestern USA. Hydrological Processes 15(1) 23-38.
Hanson, G. J., and D. M. Temple. 2002. Performance of bare-earth and vegetated steep channels under long-duration flows. Trans. ASAE 45(3): 695-701.

Hanson, G. J., K. R. Cook, and A. Simon. 1999. Determining erosion resistance of cohesive materials. In Proc. ASCE Intl. Water Resources Eng. Conf., CD-ROM. Seattle, Wash.: ASCE.

Hanson, G. J., A. Simon, and K. R. Cook. 2002. Non-vertical jet testing of cohesive streambank materials. ASAE Paper No. 022119. St. Joseph, Mich.: ASAE.

Henderson, M. B., T. M. Wynn, and D. H. Vaughan. 2006. Changes in streambank erodibility and critical shear stress due to subaerial processes. ASABE Paper No. 062144. St. Joseph, Mich.: ASABE.

Holtz, R. D., and W. D. Kovacs. 1981. An Introduction to Geotechnical Engineering. Englewood Cliffs, N.J.: Prentice Hall.

Julian, J. P., and R. Torres. 2006. Hydraulic erosion of cohesive riverbanks. Geomorphology 76(1-2): 193-206.

Kamphuis, J. W., and K. R. Hall. 1983. Cohesive material erosion by unidirectional current. J. Hydraulic Eng. 109(1): 49-61.

Kamyab, I. 1991. Streambank stability prediction for C6 stream type reconstruction. PhD diss. Reno, Nev.: University of Nevada.

Keaton, J. N., T. Messinger, and E. J. Doheny. 2005. Development and analysis of regional curves relating bankfull channel geometry and discharge to drainage area for selected gaged streams in the valley and ridge physiographic province, Maryland, Virginia. Reston, Va.: USGS.

Lambe, T. W., and R. V. Whitman. 1969. Soil Mechanics. New York, N.Y.: John Wiley and Sons.

Langendoen, E. J. 2000. CONCEPTS - Conservational channel evolution and pollutant transport system: Stream corridor version 1.0. Research Report No. 16. Oxford, Miss.: USDA-ARS

Lavelle, J. W., and H. O. Mofjeld. 1987. Do critical stresses for incipient motion and erosion really exist? J. Hydraulic Eng. 113(3): 370-393.

Lawler, D. M. 1995. The impact of scale on the processes of channel-side sediment supply: A conceptual model. In Effects of Scale on Interpretation and Management of Sediment and Water Quality. IAHS Pub. 226. Wallingford, U.K.: International Association of Hydrological Sciences.

Mamo, M., and G. D. Bubenzer, 2001a. Detachment rate, soil erodibility, and soil strength as influenced by living plant roots: Part I. Laboratory study. Trans. ASAE 44(5): 1167-1174.

Mamo, M., and G. D. Bubenzer. 2001b. Detachment rate, soil erodibility, and soil strength as influenced by living plant roots: Part II. Field study. Trans. ASAE 44(5): 1175-1181.

Nearing, M. A., G. R. Foster, L. J. Lane, and S. C. Finkner. 1989. A process-based soil erosion model for USDA water erosion prediction project technology. Trans. ASAE 32(5): 1587-1593.

Neave, H. R., and P. L. Worthington. 1988. Distribution-Free Tests. London, U.K.: Unwin Hyman.

Neill, C. R. 1967. Mean-velocity criterion for scour of coarse uniform bed-material. Proc. Intl. Assoc. for Hydraulic Res. 3: 46-54.

Neill, C. R. 1973. Guide to Bridge Hydraulics. Toronto, Canada: University of Toronto Press.

Osman, A. M., and C. R. Thorne. 1988. Riverbank stability analysis: I. Theory. J. Hydraulic Eng. 114(2): 134-150.

Osterkamp, W. R., P. Heilman, and L. J. Lane. 1998. Economic consideration of a continental sediment-monitoring program. Intl. J. Sediment Res. 13(4): 12-24.

Owoputi, L. O., and W. J. Stolte. 1995. Soil detachment in the physically based soil erosion process: A review. Trans. ASAE 38(4): 1099-1110.

Partheniades, E. 1965. Erosion and deposition of cohesive soils. $J$. Hydraulics Div. ASCE 91(HY1): 105-139. 
Prosser, I. P., A. O. Hughes, and I. D. Rutherfurd. 2000. Bank erosion of an incised upland channel by subaerial processes: Tasmania, Australia. Earth Surface Processes and Landforms 25(10): 1085-1101.

Samani, J. M. V., and N. Kouwen. 2002. Stability and erosion in grassed channels. J. Hydraulic Eng. 128(1): 40-45.

Shields, A. 1936. Application of similarity principles and turbulence research to bed-load movement. Trans. by W. P. Ott and J. C. van Uchelen. Pasadena, Cal.: California Institute of Technology, SCS Co-operative Laboratory.

Simon, A., A. Curini, S. E. Darby, and E. J. Langendoen, 2000. Bank and near-bank processes in an incised channel. Geomorphology 35(3-4): 193-217.

Smerdon, E. T., and R. P. Beasley. 1961. Critical tractive forces in cohesive soils. Agric. Eng. 42(1): 26-29.

Temple, D. M. 1980. Tractive force design of vegetated channels. Trans. ASAE 23(4): 884-890.

Temple, D. M. 1983. Design of grass-lined open channels. Trans. ASAE 26(4): 1064-1069.

Temple, D. M. 1985. Stability of grass-lined channels following mowing. Trans. ASAE 28(3): 750-754.

Temple, D. M. 1992. Estimating flood damage to vegetated deep soil spillways. Applied Eng. in Agric. 8(2): 237-242.

Temple, D. M., and G. J. Hanson. 1994. Headcut development in vegetated earth spillways. Applied Eng. in Agric. 10(5): 677-682.

Thompson, A. M., B. N. Wilson, and B. J. Hansen. 2004. Shear stress partitioning for idealized vegetated surfaces. Trans. ASAE 47(3): 701-709.

Thorne, C. R. 1982. Processes and mechanisms of river bank erosion. In Gravel-Bed Rivers, 227-259. R. D. Hey, J. C. Bathurst, and C. R. Thorne, eds. New York, N.Y.: John Wiley and Sons.
Trimble, S. W. 1997. Contribution of stream channel erosion to sediment yield from an urbanizing watershed. Science 278(5342): 1442-1444.

USACE. 1993. HEC-6: Scour and Deposition in Rivers and Reservoirs, User's Manual, Version 4.1. Alexandria, Va.: U.S. Army Corps of Engineers, Hydrologic Engineering Center.

USDA. 1996. Soil Survey Laboratory Manual Methods. Soil Survey Investigations Report No. 42, Version 3.0. Lincoln, Neb.: USDA-NRCS National Soil Survey Center.

USEPA. 2002. National Water Quality Inventory: 2000 Report. EPA 841-R-02-001. Washington, D.C.: U.S. EPA

Vanoni, V. A. 1977. Sedimentation Engineering. New York, N.Y.: ASCE.

Wallbrink, P. J., A. S. Murray, and J. M. Olley. 1998. Determining sources and transit times of suspended sediment in the Murrumbidgee River, New South Wales, Australia, using fallout ${ }^{137} \mathrm{Cs}$ and ${ }^{210} \mathrm{~Pb}$. Water Resources Res. 34(4): 879-887.

Wilson, C. A. M. E., T. Stoesser, P. D. Bates, and A. B. Pinzen. 2003. Open channel flow through different forms of submerged flexible vegetation. J. Hydraulic Eng. 129(11): 847-853.

Wynn, T. 2004. The Effects of Vegetation on Streambank Erosion. PhD diss. Blacksburg, Va.: Virginia Tech, Department of Biological Systems Engineering.

Wynn, T. M., and S. Mostaghimi. 2006a. The effects of vegetation and soil type on streambank erosion, southwestern Virginia, USA. J. AWARA 42(1): 69-82.

Wynn, T., and S. Mostaghimi. 2006b. Effects of riparian vegetation on stream bank subaerial processes in southwestern Virginia, USA. Earth Surface Processes and Landforms 31(4): 399-413.

Wynn, T., S. Mostaghimi, J. Burger, A. Harpold, M. Henderson, and L. A. Henry. 2004. Variation in root density along streambanks. J. Environ. Quality 33(6): 2030-2039. 